\title{
Thermal Performance Analysis of Parabolic Trough Solar Concentrator with Helical Tube Receiver
}

\author{
Saad Tami Hamidi Jamal Abdul-Kareem Mohammed Laith Mohsen Reda \\ Electromechanical Eng. Dep., University of Technology, Baghdad, IRAQ

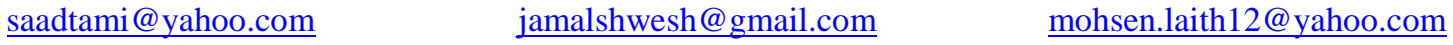 \\ Received: 20-Dec.-2017Ｒevised: 04-March-2018 Accepted: 30-April-2018
}

http://doi.org/10.29194/NJES.21030374

\begin{abstract}
In this paper, the experimental thermal performance for a parabolic trough solar concentrator (PTSC) combined with helical tube receiver and directed by two axes solar tracking system at different amount of water flow rates has been analyzed. The experimental test results of thermal performance with regard to temperature rise of water, useful heat gain and collector thermal efficiency for the PTSC prototype at controlled water flow rates $(2.3,22.5$ and 29.4 $\mathrm{L} / \mathrm{h}$ ) are collected. The results show that the increase of water mass flow rates causes decrease in the average water output temperature as (120.8, 63.82 and $46.08^{\circ} \mathrm{C}$ ), respectively, the maximum outlet temperature becomes $(160.5,76,47){ }^{\circ} \mathrm{C}$, respectively, and thus, the average useful heat gain will be $(1249.4,732,732.5 \mathrm{~W})$, respectively and the average thermal efficiency decreases as (73.021, 49.51 and $44.31 \%$ ), respectively. The experimental results show that decrease the water mass flow rate by $74.4 \%$, causes an increase in the thermal efficiency of the PTSC by $64.7 \%$.
\end{abstract}

Keywords: Solar Concentrators, Helical Receiver, Water Flow Rate, Tracking System

\section{Introduction}

Renewable energy, especially, solar energy is one of the main sources, widely used in different industrial and domestic applications. Solar energy equipments like Parabolic Trough Solar Collector (PTSC) have been extensively acknowledged by the society. The PTSC technology is the most proven and lowest cost large-scale solar power technology available today. The PTSCs are devices used to extract energy from solar radiation to a working fluid, which can be utilized for various applications, like water heating, space heating and power generation. Most studies in this field focus on how to enhance the thermal performance of the solar collector. Folaranmi, 2009 [1] designed, built and carried out experiments on a solar parabolic dish steam generator. He used a concentrated collector to concentrate the heat comes from the sunrays on a black collector placed at the focal point of the reflector at which the water temperature is elevated to a very high levels enough to generate steam. A manual sun tracking system unit was used to direct the dish reflector so as the sun is always perpendicularly oriented towards the collector during the daytime for capturing solar energy. The test results shown that the system had been gave a high temperature above $200^{\circ} \mathrm{C}$ at average sunny and cloud free days. Mohammed, 2012 [2] designed and developed a water heater based on solar parabolic dish to heat water up to $100^{\circ} \mathrm{C}$ for domestic application. To increase the thermal efficiency, a linear actuator was used to track the sun. Experimental tests shown that the thermal efficiencies were between (52-56)\%. This range is more than the design value with 50\%. V.-Reyes, et al. 2012 [3] designed, constructed, and evaluated the performance of a PTC with a $45^{\circ}$ rim angle, $4.88 \mathrm{~m}$ length, and 5.8 $\mathrm{m}^{2}$ aperture area. The PTC was made up of aluminium. It was designed with an unshielded receiver and without a glass cover so as to decrease the costs for both production and transportation. A simple sun tracking system had been used when it was directed in a North to South direction. The PTC thermal performance was decided according to the Standard ASHRAE 93-1986 (RA 91). Maximum efficiencies near to 60\% were achieved. Mohammed, 2013 [4] designed and constructed a parabolic dish solar thermal food cooker to cook about $12 \mathrm{~kg}$ dry rice daily. To get good performance, the solar cooker was combined with solar tracker and linear actuator. The experimental results shown that the food cooker was able to cook $3 \mathrm{~kg}$ of rice through (90 - 100min), which highly matches the expected time of $91 \mathrm{~min}$. Sundari, et al. 2013 [5] designed a forced convection solar drier combined with evacuated tube collector and a air blower. The proposed solar drying was carried at different air velocity flow rates $(4,4.25$ and $4.5 \mathrm{~m} / \mathrm{s})$ and was compared with natural sun drying. It was observed that the drier efficiency increased with increase in air velocity flow rates. M. Valencia, et al. 2014 [6] presented the steps of design, modelling, and evaluation of a demonstrative PTC prototype for heating water. The PTC design was presented the parabolic aperture wide of $0.5 \mathrm{~m}$ and long of $0.95 \mathrm{~m}$. The system thermal performance evaluation results had a maximum value of outlet temperature of $47.3^{\circ} \mathrm{C}$ for a direct sun radiation of 
$783 \mathrm{~W} / \mathrm{m}^{2}$ at a mass flow rate of $0.2 \mathrm{~L} / \mathrm{min}$. Sakhare and Kapatkar, 2014 [7] experimentally designed and developed the performance characteristics of a fixed (without tracking) solar parabolic dish concentrating system with helical coiled collector for the application of steam generation. The performance had been experimentally investigated with circulated water (heat transfer fluid). The system had been manufactured with high reflective foil sheet stainless steel. The experimental results were obtained on summer and non-cloudy days. The efficiency of the solar steam conversion was (6070) $\%$ at temperature measured with $215^{\circ} \mathrm{C}$. Masood, et al. 2016 [8] discussed the viewpoints of the primary design and development for a PTC system. This study also involves the analysis of thermal performance of a designed solar parabolic trough field by using System Advisor Model (SAM). The simulation results showed that the temperature of heat transfer fluid might reach $(200-230)^{\circ} \mathrm{C}$. This range could be utilized to work an unfired boiler to generate steam or other industrial thermal application. Kulkarni, 2016 [9] designed and developed a solar collector prototype with a cylindrical parabolic shape. The collector has aperture area of $1.89 \mathrm{~m}^{2}$, fabricated of material with low cost, high reflection and absorption so as to reduce the initial cost of work project and enhance thermal efficiency. This system could produce hot water with an average temperature of $50^{\circ} \mathrm{C}$ per day and an average efficiency of $49 \%$. These values are considerably higher than the flat plate solar collectors. The hot water generated by this technique could be beneficial in agricultural, domestic, and industrial process heat applications. Pavlovic, et al, 2016 [10] presented an analysis for the optical and thermal performance of a parabolic dish solar concentrator containing a spiral coil receiver. The dish reflector contains eleven curvilinear trapezoidal reflective petals built by PMMA with silvered mirror layer and has a $3.8 \mathrm{~m}$ diameter and $2.26 \mathrm{~m}$ focal distance. In the thermal analysis part, the energetic efficiency had been calculated to be approximately $65 \%$, while the exegetic efficiency was varied from (4-15\%) according to the water inlet temperature. D. Kumar and S. Kumar, 2017 [11] experimentally investigated the thermal performance of a PTC at different working fluid flow rates. The PTC was built as a simple structure with a non-evacuated tube and tested in tracking and south-facing modes utilizing the water as a working fluid. The thermal performance regarding to water temperature rise, useful heat gain, and collector efficiency were evaluated with and without utilizing glazing on the receiver. Results had been shown that collector performance mainly is depending on the water mass flow rate. It was noted that no considerable variation was found with water flow rate more than $0.024 \mathrm{~kg} / \mathrm{s}$. Also, found that the small-sized PTC gives a slight better performance in the south-facing than the tracking mode.

The aim of the present work is to experimentally analyse the thermal performance of the solar parabolic trough concentrator combined with a helical tube receiver, as new technique, at different values of water flow rate. The concentrator is directed by two-axis tracking system to get maximum energy of solar radiation.

\section{Experimental Work}

The experimental setup for the solar parabolic trough concentrator consists of two parts. The first part represents the parabolic trough solar collector while the other is the tracking system.

\subsection{Description of the Parabolic Trough Solar Concentrator (PTSC)}

The PTSC was easily constructed with low cost materials. A stainless steel mirror sheet of size $(1750 \times 1000) \mathrm{mm}$ with $1 \mathrm{~mm}$ thickness placed longitudinally on the PTSC frame was used as a reflector to reflect about $65 \%$ of sunrays [12]. The mirror sheet is placed on the system structure without any modification, where the parabolic profile is specified by the shape of the ribs and rest on side ribs. The collector sheet has been designed according to software program (parabola calculator v.2.1). The designed parameters for the PTSC were found as listed as in Table 1 . In order to efficiently benefit by most of the solar reflected radiation, the sun rays must be highly concentrated on the receiver. In this system, copper helical receiver tube is used as a new technique.

Table 1: Specifications of PTSC

\begin{tabular}{|c|c|}
\hline Item & Value/Type \\
\hline Collector aperture area & $1.755 \mathrm{~m}^{2}$ \\
\hline Aperture width & $1 \mathrm{~m}$ \\
\hline Length / Aperture ratio & 1.755 \\
\hline Rim angle & 90 degrees \\
\hline Receiver diameter & $25 \mathrm{~mm}$ \\
\hline Concentration ratio & 17 \\
\hline Focal length & $250 \mathrm{~mm}$ \\
\hline Tracking mechanism type & Electro/optical \\
\hline Mode of tracking & Two axes tracking \\
\hline
\end{tabular}

This receiver has long of $1835 \mathrm{~mm}$ depending on the length of the collector, diameter roll of tube $\left(d_{o}\right)$ is $6.35 \mathrm{~mm}$ and thickness of the tube is $0.61 \mathrm{~mm}$ and the length of the coiled tubes $\left(N_{\text {coil }}\right)$ is $15 \mathrm{~m}$, the number of windings of the tube is 116 rolls and roll diameter is $38.6 \mathrm{~mm}$ and the average distance between any roll and the other (coil $p_{i t c h}$ ) 
is $14.35 \mathrm{~mm}$. Two expanded copper pieces are used to expand the diameter at the ends of the tube, mounted by welding in order to link the tube with the tube which connected with a water tank. The helical tube is placed inside a glass tube opening from both sides so as to reduce the thermal losses. Fig. 1 shows the outline of the helical tube.

The size of the helical tube is designed on the basis of the diameter of the glass tube in which the helical tube is placed inside. There is no flexibility in choosing the glass tube because this tube with the current dimension is the available in the native markets. The helical pipe was manually wrapped according to the glass tube dimensions.

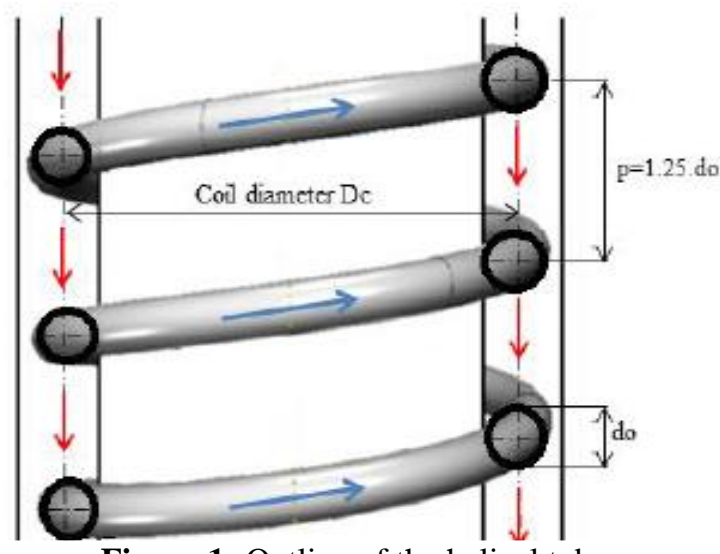

Figure 1: Outline of the helical tube

The following equation has been used to design the helical tube receiver [13].

The helical coil length is calculated according to the following equation:

$$
L_{\text {coil }}=N_{\text {coil }} \sqrt{\left(\pi d_{o}\right)^{2}+p_{\text {itch }}^{2}}
$$

, where $N_{\text {coil }}$ is the number of the coils in the helical tube, do is the coil outer diameter, and $p_{i t c h}$ is the average distance between each two neighboring turns in the helical tube.

The focal length can be determined from the following equation:

$$
f=\frac{W_{a}}{4 \tan \left(\phi_{r} / 2\right)}
$$

, where, $f$ : is the focal length in $\mathrm{m}, W_{a}$ : is aperture width in $\mathrm{m}, \Phi_{r}$ : is the rim angle in degree.

From the following equations, the aperture area of the parabolic trough $A_{p}$ in $\mathrm{m}^{2}$, the area of receiver $\mathrm{A}_{\mathrm{r}}$ in $\mathrm{m}^{2}$, and Concentration Ratio C.R can be calculated as:

$$
\begin{aligned}
& A_{\mathrm{p}}=\mathrm{W}_{\mathrm{a}} \times \mathrm{L} \\
& \mathrm{A}_{\mathrm{r}}=\mathrm{D}_{\mathrm{r}} \times \mathrm{L}_{\mathrm{r}}
\end{aligned}
$$

Concentration Ratio,

$$
\text { C.R. }=\frac{A_{p}}{A_{r}}
$$

, where, $D_{r}$ : is the diameter of receiver in $\mathrm{m}, L=$ $L_{r}=$ Length of parabolic trough in $\mathrm{m}$

\subsection{Tracking system}

To get efficient performance, the proposed design requires that the PTSC tracks the sunrays permanently sun - earth angles shown in Fig. 2.

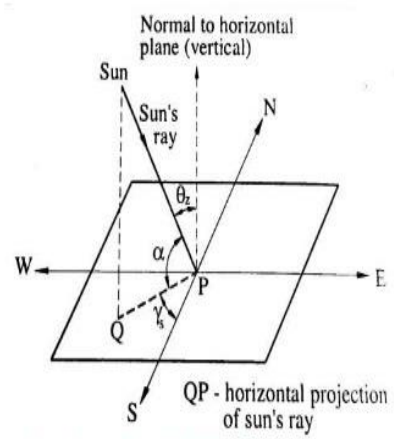

\section{Inclination Angle (Altitude) $(\alpha)$}

\section{Zenith Angle $\left(\theta_{2}\right)$ \\ 3. Solar Azimuth Angle $\left(\gamma_{\mathrm{s}}\right)$}

Figure 2: Sun - Earth angles [14]

Therefore, designing and developing an automated control circuit is needed to achieve this purpose. Two axis tracking system is employed to direct the PTSC system to the sun rays. The tracker system consists of (fix part, moving part, control circuit and channel relays). The fixed part, called the base, is used to mount the whole system on it. The moving part consists from two different motions; 1) the axial motion to move the PTSC from east to west to track the sun rays via using a $12 \mathrm{~V}$ DC gear box and 2) tilting motion to move the PTSC upper and lower, this motion may be directed by using a $12 \mathrm{~V}$ DC motor to produce a linear movement as shown in Figs. 3 ( $a$ and $b$ ). The control circuit consists of Arduino UNO, light dependent resistances (LDRs) as shown in Fig. 4. Four channel relay circuit is used to receive signals appropriate to drive the system in the four directions. The block diagram in Fig. 5 shows the procedure processing of two-axis tracker system. 


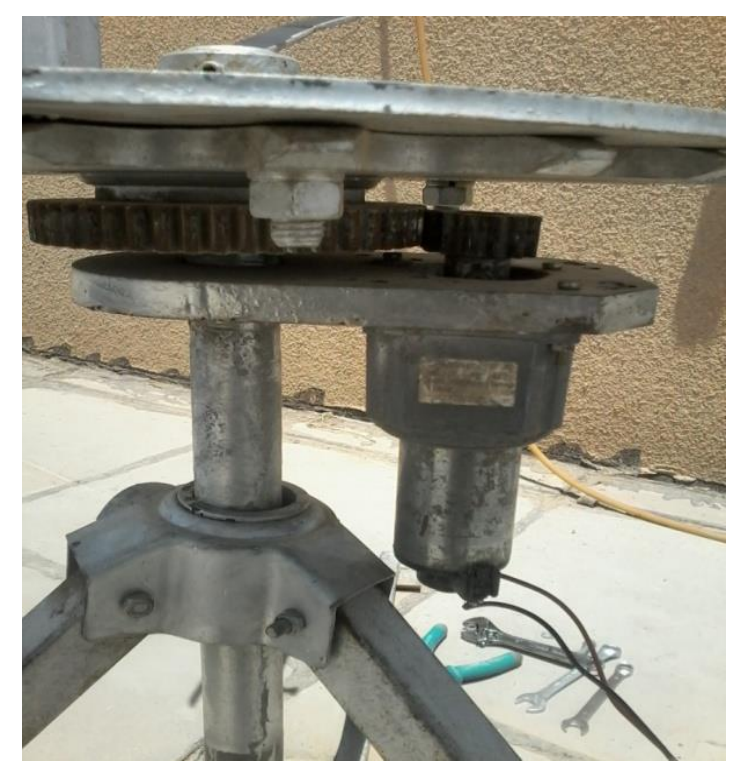

Figure 3a: DC gear box

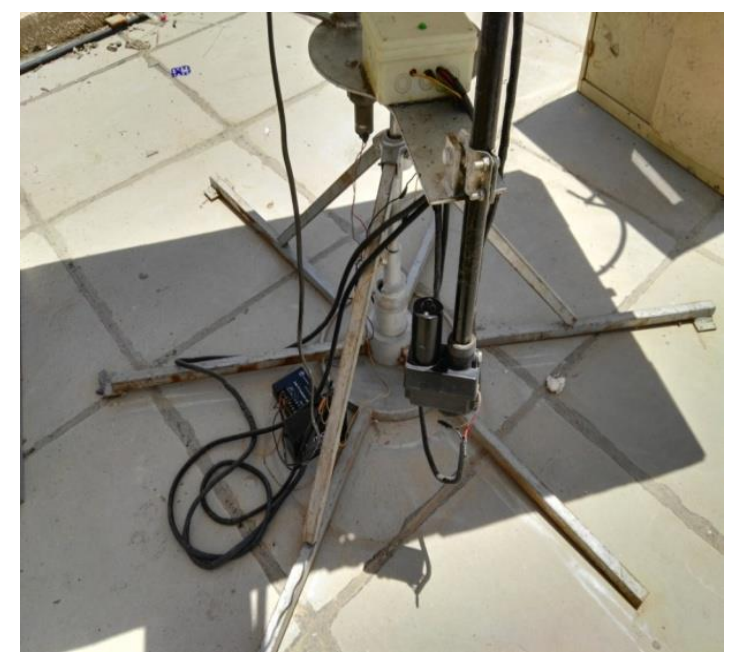

Figure 3b: Linear DC motor

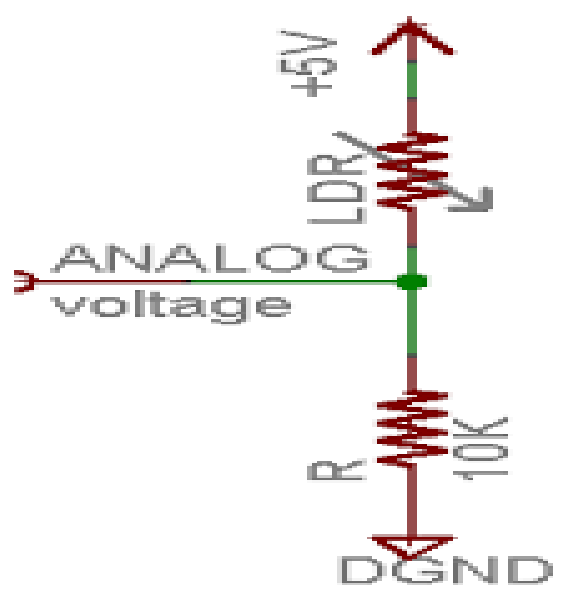

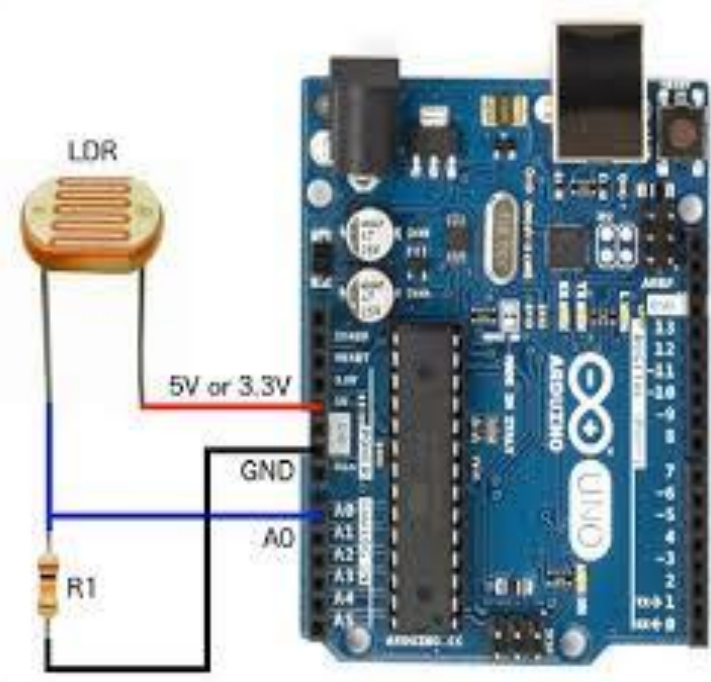

Figure 4: LDR with Arduino UNO [15].

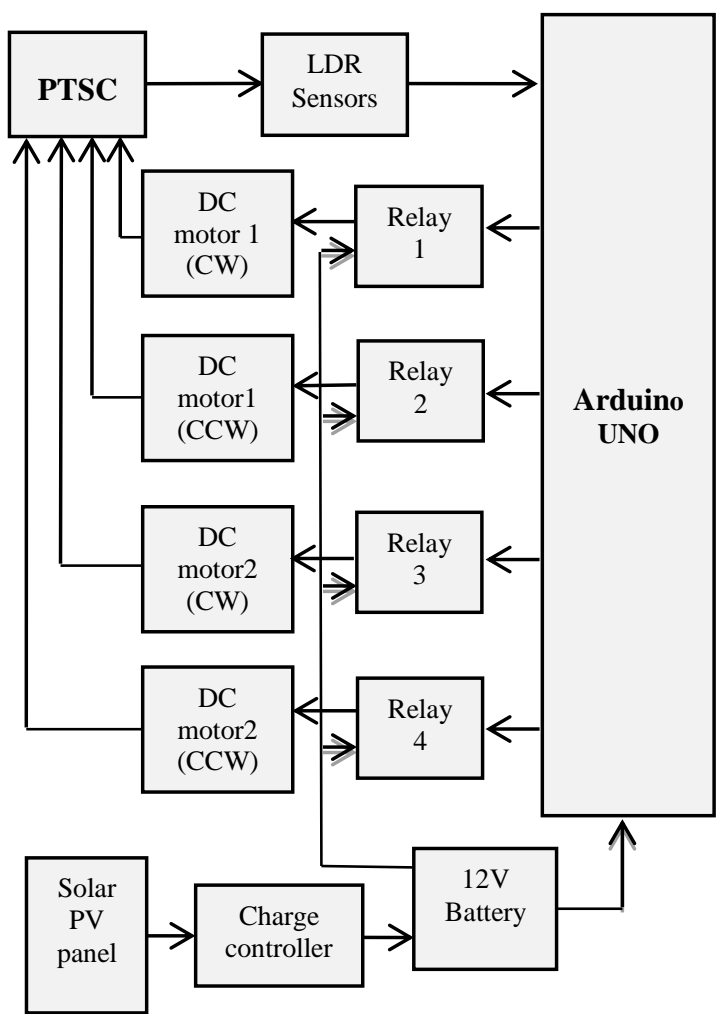

Figure 5: Block diagram shows operation of the tracking system with PTSC

\section{Experimental Setup and Concentrator Testing}

The proposed PTSC had been adjusted and prepared for performance evaluation test at Baghdad city. The testing area and experiment was prepared as shown in Fig. 6. The PTSC experimental setup is combined with a storage water tank of 1000 litres capacity, kept at $0.5 \mathrm{~m}$ above the PTSC level to keep natural flow of working fluid (water) inside the PTSC. The test was open loop controlled with variable mass flow rates of water at values of $(2.3,22.5$ and 29.4 
Liter/h). The measurement parameters adopted during the test were water temperature inlet $\mathrm{T}_{\text {inlet }}$, water temperature outlet $\mathrm{T}_{\text {outlet, }}$ atmospheric temperature $\mathrm{T}_{\mathrm{amb}}$, solar radiation $\mathrm{I}$ watt $/ \mathrm{m}^{2}$, and velocity of the air $\mathrm{m} / \mathrm{s}$. K-type thermocouple was used for measuring atmospheric temperature and water temperature inlet and outlet, simultaneously. The temperatures of water at inlet, outlet and ambient temperature were measured using BTM-4208SD 12 channels temperature recorder with resolution of $0.1^{\circ} \mathrm{C} /$ $1^{\circ} \mathrm{C}$. The air velocity was measured by thermo Anemometry ranged with the range of $(0-15 \mathrm{~m} / \mathrm{s})$ and accuracy of $\pm 0.2 \mathrm{~m} / \mathrm{s}$. A TES-1333R Data logging solar power meter was utilized to measure the intensity of sun radiation, ranged with $(0-$ $2500 \mathrm{~W} / \mathrm{m}^{2}$ ) with resolution of $0.1 \mathrm{~W} / \mathrm{m}^{2}$ and accuracy of $\pm 10 \mathrm{~W} / \mathrm{m}^{2}$. An Arduino UNO controller board based on ATmega328P microcontroller was used to direct the PTSC to sun rays via using four LDR solar sensors. The Arduino receives the signals from these sensors when exposed to sunlight and the uses them to drive the DC motors to the desired direction with respect to the sun. A $13 \mathrm{~W}, 12 \mathrm{~V}$ solar PV cells was used to charge a $12 \mathrm{~V}$ battery necessary for supplying the motors and the controller. The sensors of the solar energy radiation fixed on the collector aperture send electric signals to the DC motor which, in turn, organize the location of the parabolic concentrator till getting maximum intensity of solar radiation at the aperture.

Useful heat gain and thermal efficiency of the water was experimentally calculated according to change the water phase from liquid to steam as a part of the time daily test. The diagram shown in Fig.7 represents the heating curve of the water. There are five labelled sections on the plotted lines.

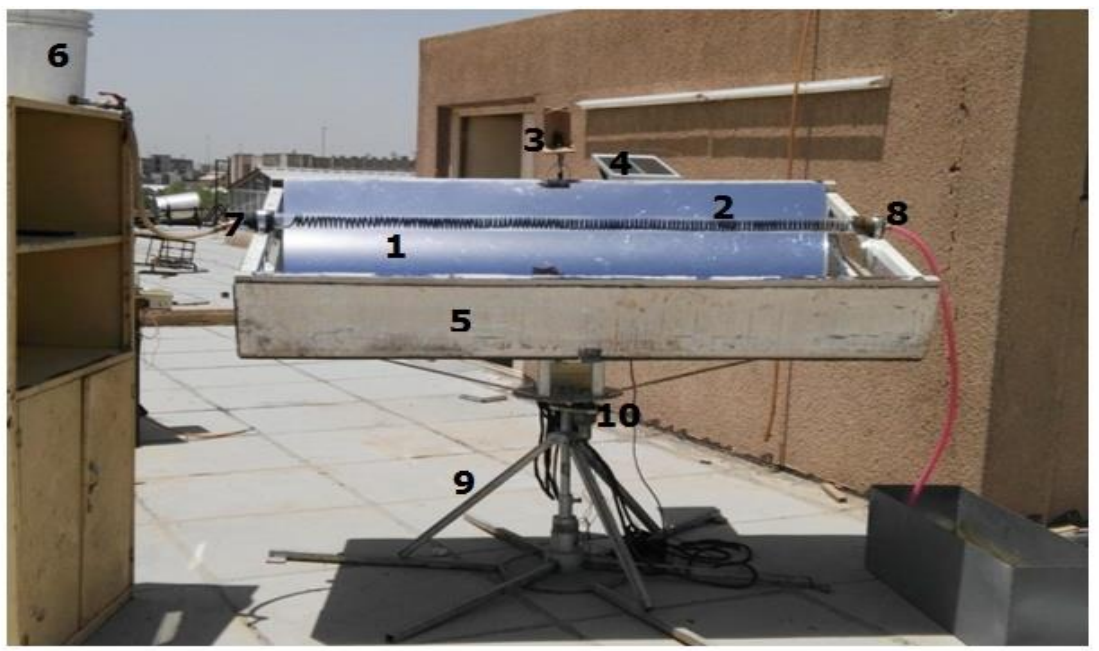

Figure 6: Experimental system setup: 1. stainless steel reflector, 2. helical tube with glass cover 3. wind instrument, 4. PV cells, 5. aero foam insulation, 6. tank of water, 7. inlet water to the collector, 8. outlet water from the collector, 9. iron supports and 10. DC gear box.

\section{Heating Curve for Water}

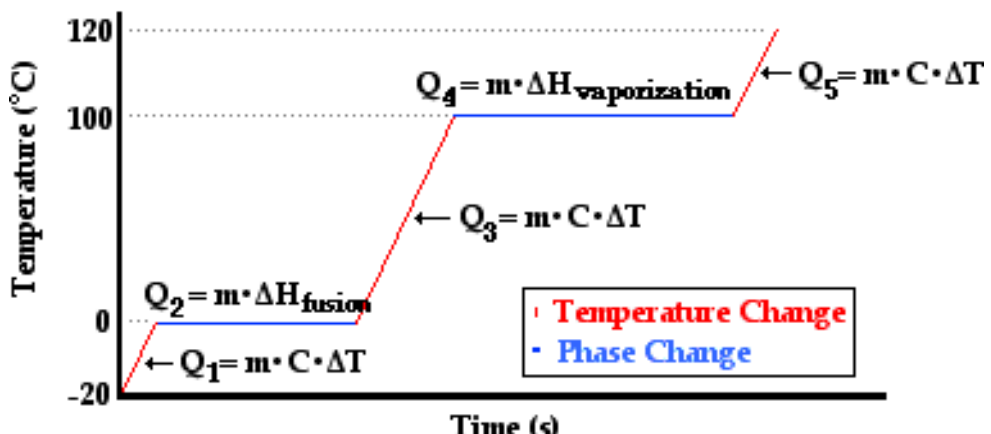

Figure 7: Water Heating Curve

All the equations necessary to analysis the thermal performance of the PTSC are given as follows:

The total useful heat gain of the concentrator can be calculated as [16]:

$$
\begin{aligned}
& \mathrm{Q}_{\mathrm{T}}=\sum \mathrm{Q}=\mathrm{Q}_{\text {Liquid (sensible heat) }}+\mathrm{Q}_{\text {Vaporization (latent heat) }} \\
& \quad+\mathrm{Q}_{\text {Steam (vapor heat) }}
\end{aligned}
$$


(When the output temperature is less than $100 \mathrm{C}^{\circ}$ and $\mathrm{C}_{\mathrm{p}}=4200 \mathrm{~kJ} / \mathrm{kg} . \mathrm{C}, \Delta \mathrm{T}=\left(100-\mathrm{T}_{\text {outlet }}\right)$.

$\mathrm{Q}_{\text {Vaporization (latent heat) }}=\mathrm{m}^{*} \Delta \mathrm{H}_{\text {vaporization }}$

(When the output temperature is equal $100 \mathrm{C}^{\circ}$ and $\Delta \mathrm{H}_{\text {vaporization }}=2256 \mathrm{~kJ} / \mathrm{kg}$ )

$\mathrm{Q}_{\text {Steam (vapor heat) }}=\mathrm{m}^{*} \mathrm{C}_{\mathrm{p}} \Delta \mathrm{T}$

(When the output temperature is more than $100 \mathrm{C}^{\circ}$ and $\mathrm{C}_{\mathrm{p}}=2000 \mathrm{~kJ} / \mathrm{kg} . \mathrm{C}, \Delta \mathrm{T}=\left(\mathrm{T}_{\text {outlet }}-100\right)$

From the collected experimental results, the useful gain and efficiency of the PTSC can be evaluated as:

$$
Q=\frac{\sum Q_{a v}}{N}
$$

$Q$ : is the instantaneous useful heat gain and $Q_{a v}$ is the average value of useful heat gain, $\mathrm{N}$ : is the number of reading measurements.

After obtaining the useful heat gain, the instantaneous thermal efficiency $\eta$ and average efficiency $(\eta)_{\text {ave }}$ of the PTSC may be found by applying the following equations, respectively:

$$
\begin{aligned}
& \eta=\frac{m^{*} C_{P} \int\left(T_{O}-T_{i}\right) d t}{A_{C} \int(I) d t} \\
& \eta_{\text {ave }}=\frac{\sum \eta}{N}
\end{aligned}
$$

\section{Results and Discussion}

The experiments were carried out, under climatic conditions of Baghdad city, to investigate the influences of varying mass water flow rates on the performance of the PTSC equipped with helical tube and directed by two axis tracking system during period from (9 am to $3 \mathrm{pm}$ ). The experimental results were recorded every 1 hour and the thermal performance was presented in Figs. (8-14) for different days at the same flow rate of water. Fig. 8 demonstrates the average change of sun radiation intensity measured in the days $\left(10^{\text {th }}, 18^{\text {th }}\right.$ and $\left.22^{\text {th }}\right)$ of May 2017. The average intensity solar radiation measured on the same PTCS using two-axis tracking system for times (9am to $3 \mathrm{pm})$ were $(962,845$ and 941 Watt), respectively.

An experiment had been conducted in the days $\left(17^{\text {th }}-18^{\text {th }}\right)$ of May 2017 to compare the performance of the PTSC combined with helical tube or a straight tube, where the tubes are made from copper metal, with the use of the two axis solar tracking system and the flow rate of water equal to 22.5 liters/hour. The results in Figs. (911) show that when using the helical tube, the output temperature, useful heat gain and thermal efficiency increase by $27.3 \%, 29.6 \%$ and $35.2 \%$, respectively as compared with the straight tube. Therefore, it can be concluded that the helical tube with tracking system is more efficient than the straight tube.

Fig.12 shows the outlet temperature with different values of flow rates $(2.3,22.5$ and $29.4 \mathrm{~L} / \mathrm{h})$ in the days $\left(10^{\text {th }}, 18^{\text {th }}\right.$ and $\left.22^{\text {th }}\right)$ of May 2017. The average outlet temperature of water was found to be $\left(120.84,63.82\right.$ and $\left.46.08 \mathrm{C}^{0}\right)$, respectively. It can be noted from the figure that the maximum values of outlet temperature at midday were $(160$, 76.4 and $50.4^{\circ} \mathrm{C}$ ), respectively.

The steam generated confirms that the spiral tube is very efficient for generating steam when using in the parabolic thermal system. This steam can be used in multiple applications like power generation, heating of buildings, desalination, fermentation and other applications.

Also it is noticed from the figure that the outlet water temperature rises gradually until time of $12: 30 \mathrm{pm}$ and then begin to drop because the solar radiation falling on the solar collector decreases and shadow effect of the grooves of the absorber surface which reduces the energy collected and increases thermal losses from the solar collector. It can be say, during the morning, all radiation was readily absorbed by receiver tube, and so, mean tube temperature and outlet water temperature increase at minimum heat loss. Fig. 13 shows useful heat gain of water in the days $\left(10^{\text {th }}, 18^{\text {th }}\right.$ and $\left.22^{\text {th }}\right)$ of May 2017 and at the same time. The average useful heat gain of water was found as (1249.4, 732 and $732.5 \mathrm{~W})$, respectively. It can be shown from the figure that maximum values of the useful heat gain at midday were about $(1723.1,1031.6$ and $785.4 \mathrm{~W})$, respectively when the water mass flow rate through the helical tube was $(2.3,22.4$ and $29.5 \mathrm{~L} / \mathrm{h})$, respectively. Fig. 14 shows the instantaneous efficiency of the solar collector during daylight hours. There is a gradual increase in efficiency due to cold water at the beginning of the day and to a gradual increase of the heat gain until midday and after that it starts to decrease gradually. Also it is noticed that the maximum of thermal efficiency at midday is $(99.8 \%, 67.4 \%$ and $47.8 \%$, when the water mass flow rate through the helical tube is $(2.3,22.4$ and $29.5 \mathrm{~L} / \mathrm{h}$ ), respectively. From the figure, it could conclude that the average efficiency of solar collector during time daily between (9am - 3pm) in the days $\left(10^{\text {th }}, 18^{\text {th }}\right.$ and $\left.22^{\text {th }}\right)$ of May 2017 is (73.021, 49.51 and $44.31 \%$ ), respectively. The Fig. 15 shows the relationship between thermal efficiency and mass flow rate when using the helical tube. It can be shown that the PTSC thermal efficiency is inversely proportional to the mass flow rate of water. 


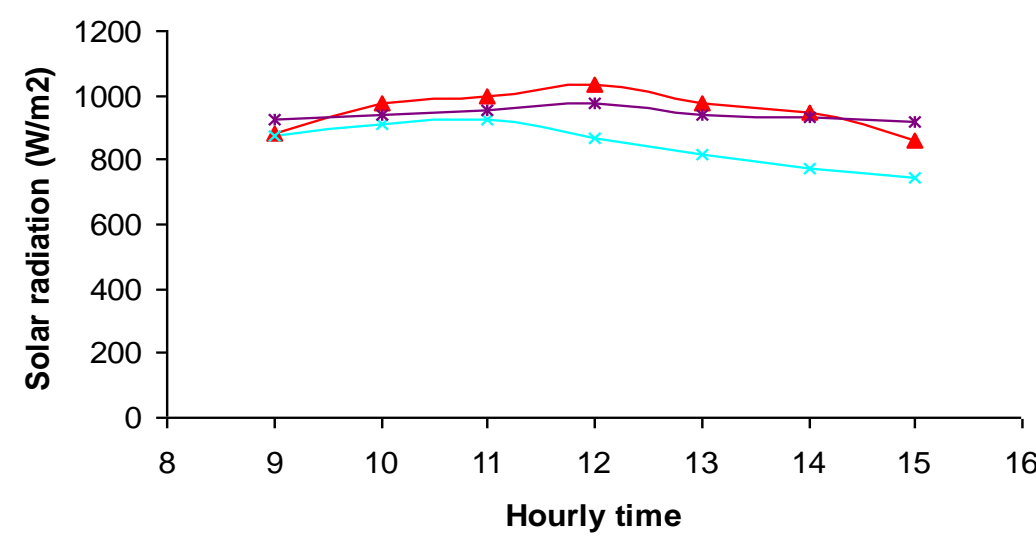

Figure 8: Solar radiation

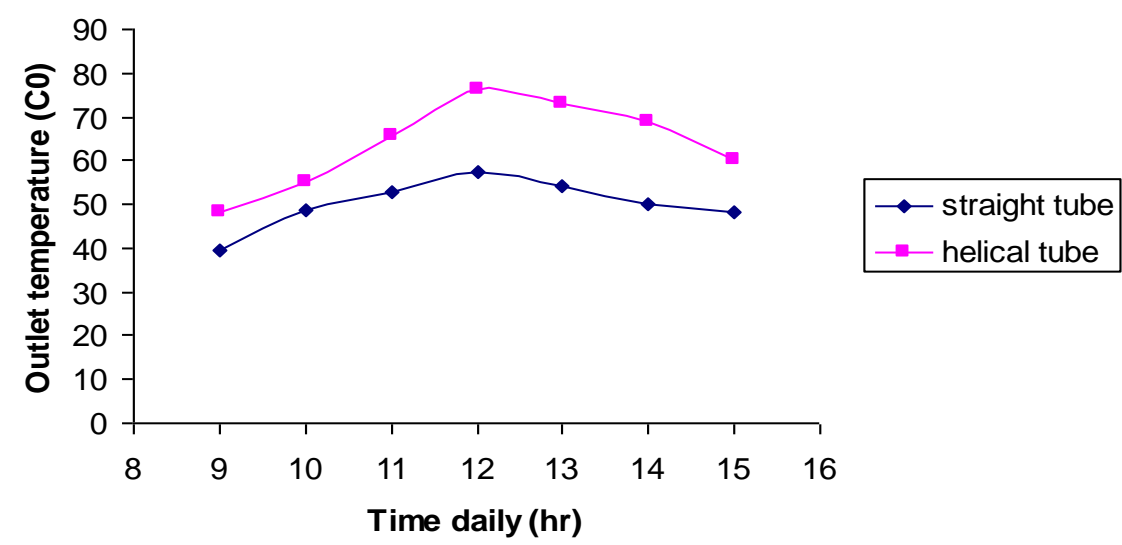

Figure 9: Comparison of the Outlet temperature between helical tube and straight tube with tracking on $\left(17^{\text {th }}\right.$, $18^{\text {th }}$ ) May 2017 with mass flow rate $22.5 \mathrm{~L} / \mathrm{h}$

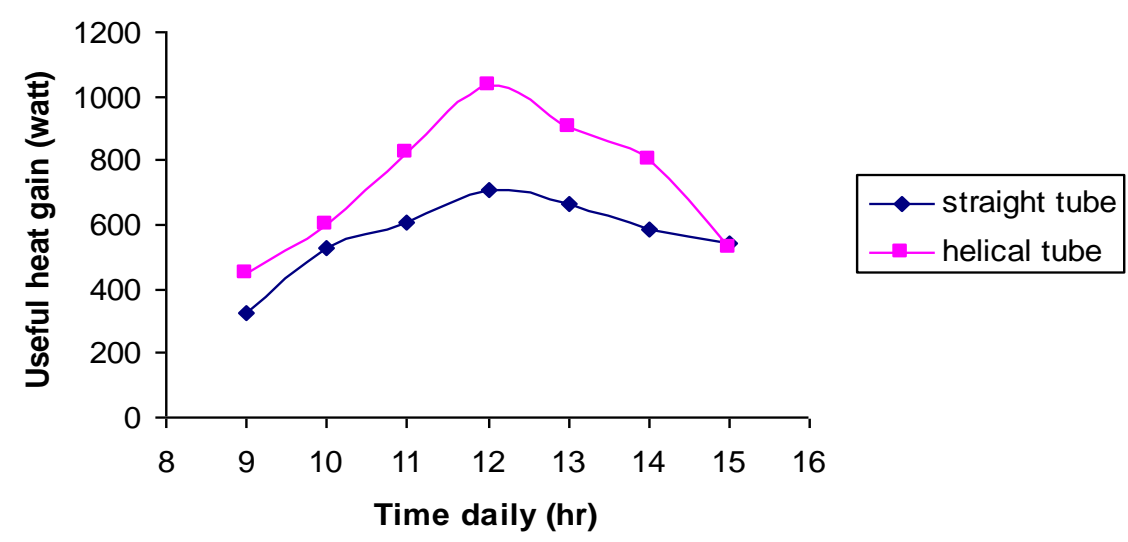

Figure 10: Comparison of the Useful heat gain between helical tube and straight tube with tracking on $\left(17^{\text {th }}\right.$, $18^{\text {th }}$ ) May 2017 with mass flow rate $22.5 \mathrm{~L} / \mathrm{h}$ 


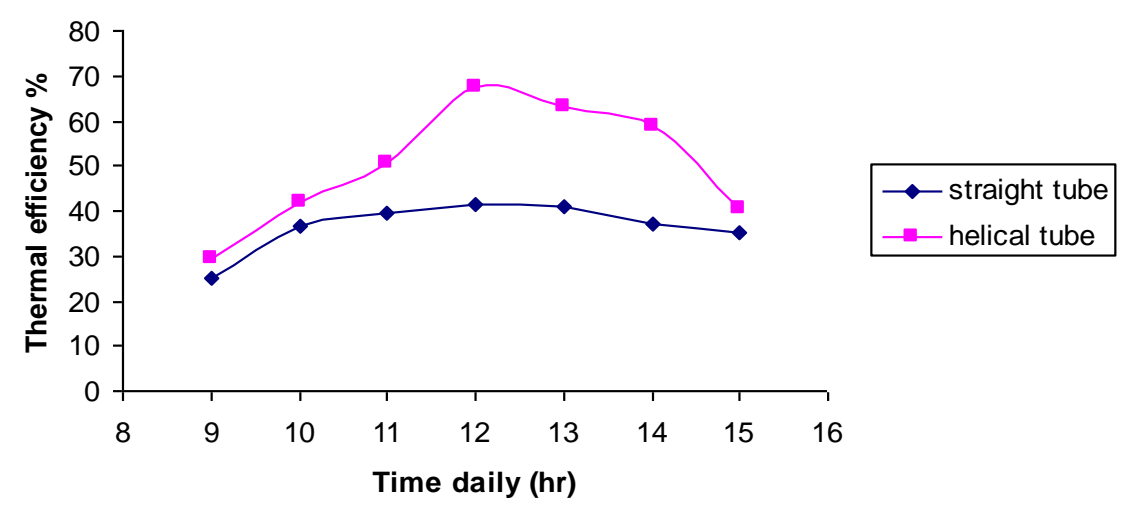

Figure 11: Comparison of the Thermal efficiency between helical tube and straight tube with tracking on $\left(17^{\text {th }}, 18^{\text {th }}\right)$ May 2017 with mass flow rate $22.5 \mathrm{~L} / \mathrm{h}$

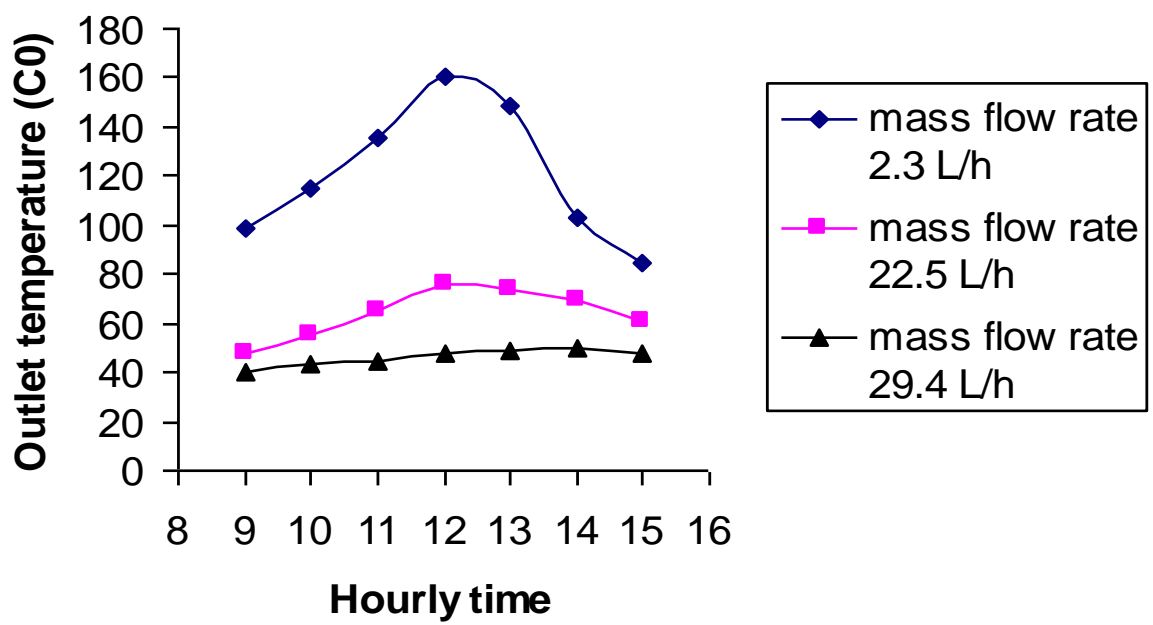

Figure 12: Water outlet temperature on $\left(10^{\text {th }}, 18^{\text {th }}, 22^{\text {nd }}\right)$ May 2017

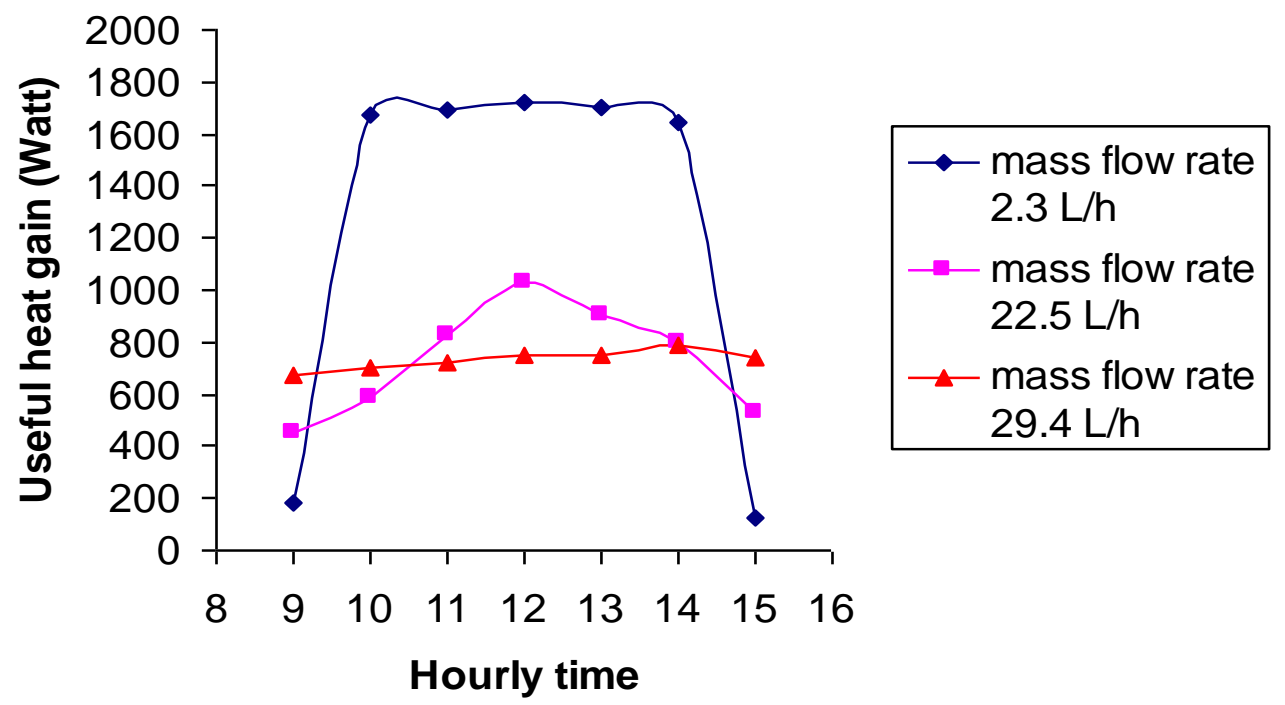

Figure 13: Water useful heat gain on $\left(10^{\text {th }}, 18^{\text {th }}, 22^{\text {nd }}\right)$ May 2017 


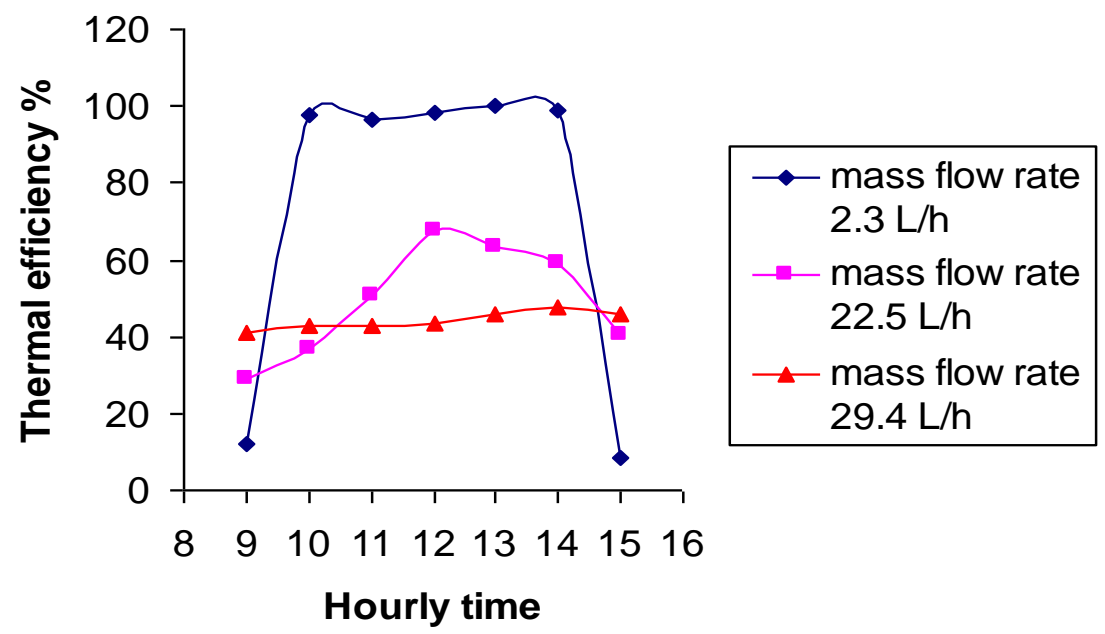

Figure 14: Thermal efficiency on $\left(10^{\text {th }}, 18^{\text {th }}, 22^{\text {nd }}\right)$ May 2017

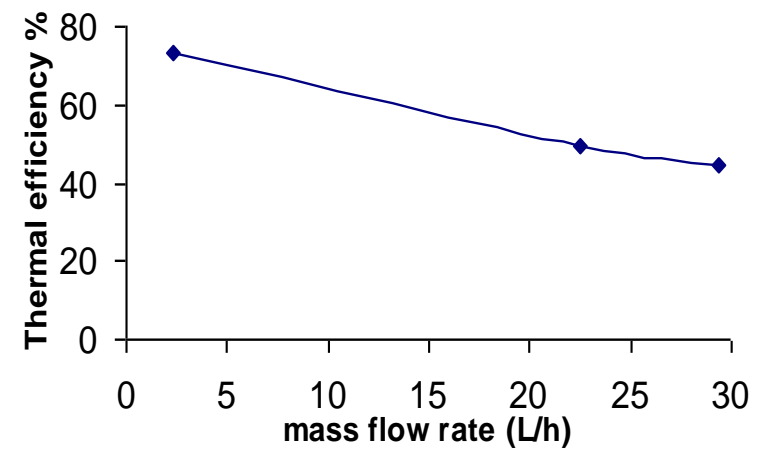

Figure 15: Percentage change of thermal efficiency of PTSC versus mass flow rate

\section{Conclusions}

The thermal performance of a parabolic trough solar concentrator is enhanced by using a helical tube receiver and directed with two axis solar tracking system. The system performance is analysed at different amount of water flow rates. From experimentation and thermal performance evaluation, some conclusions could be drawn. The incident solar radiation and tracking action are very important parameters which directly affect the thermal performance of the solar concentrator. The proposed solar concentrator generates hot water reaches to (steam phase) up to $160 \mathrm{C}^{0}$. The maximum thermal efficiency of parabolic trough solar concentrator prototype was found to be $99.8 \%$ at water mass flow rate of $2.3 \mathrm{~L} / \mathrm{h}$. The experimental results show that the mass flow rate is inversely proportional to thermal the efficiency that is, decreasing the mass flow rate by $74.4 \%$ causes increasing in the thermal efficiency of the solar concentrator by $64.7 \%$.

\begin{tabular}{|c|c|c|}
\hline \multicolumn{3}{|c|}{ Nomenclature } \\
\hline$A p$ & Aperture area & $\mathrm{m}^{2}$ \\
\hline$f$ & Focal length & $\mathrm{m}$ \\
\hline$W_{a}$ & aperture width & $\mathrm{m}$ \\
\hline$\Phi_{r}$ & Rim angle & Deg. \\
\hline$A_{r}$ & area of receiver & $\mathrm{m}^{2}$ \\
\hline$D_{r}$ & diameter of receiver & $\mathrm{m}$ \\
\hline$L=L_{r}$ & length of parabolic trough & $\mathrm{m}$ \\
\hline$d_{o}$ & diameter roll of tube & $\mathrm{m}$ \\
\hline$L_{\text {coil }}$ & length of the coiled tube & $\mathrm{m}$ \\
\hline$N_{\text {coil }}$ & number of tube turns & - \\
\hline$p_{\text {itch }}$ & distance between two rolls & $\mathrm{m}$ \\
\hline$C p$ & $\begin{array}{l}\text { Specific heat capacity of } \\
\text { water at constant pressure }\end{array}$ & $\mathrm{kJ} / \mathrm{kg} . \mathrm{K}$ \\
\hline$I$ & Solar radiation & $\mathrm{W} / \mathrm{m}^{2}$ \\
\hline$N$ & No. of readings & - \\
\hline$Q_{U}$ & Useful heat gain & $\mathrm{W}$ \\
\hline$T_{\text {inlet }}$ & Fluid inlet temperature & ${ }^{\circ} \mathrm{C}$ \\
\hline$T_{\text {outlet }}$ & Fluid outlet temperature & ${ }^{\circ} \mathrm{C}$ \\
\hline$m^{*}$ & mass flow rate & $\mathrm{kg} / \mathrm{s}$ \\
\hline$\eta$ & Thermal efficiency & $\%$ \\
\hline
\end{tabular}




\section{References}

[1] J. Folaranmi, "Design, Construction and Testing of a Parabolic Solar Steam Generator", Leonardo Electronic Journal of Practices and Technologies, Issue 14, 2009, pp. 115-133.

[2] I.L. Mohammed, "Design and Development of a Parabolic Dish For Solar Water Heater", Int. Journal of Eng. Research and Applicat. (IJERA), Vol. 2, Issue 1, 2012, pp. 822-830.

[3] E.V. Reyes, O.A. Jaramillo, R.C. García, J.O. Aguilar, F.S. Montemayor, "Design, construction, and testing of a parabolic trough solar concentrator for hot water and low enthalpy steam generation", Journal of Renewable and Sustainable Energy, Vol. 4, Issue 5, 2012.

[4] I.L. Mohammed, "Design and Development of a Parabolic Dish Thermal Cooker", Int. Journal of Eng. Research and Applicat. (IJERA), Vol. 3, No. 4, 2013, pp. 1179-1186.

[5] AR.U. Sundari, P. Neelamegam, C.V. Subramanian, "Performance Evaluation of a Forced Convection Solar Drier with Evacuated Tube Collector for Drying Amla", Int. Journal of Eng. and Tech., Vol. 5, No. 3, 2013, pp. 2853-2858.

[6] J.M. Valencia, J.R. Ávila, R. Acosta, O.A. Jaramillo, J.O. Aguilar, "Design, construction and evaluation of parabolic trough collector as demonstrative prototype", Energy Procedia, Vol.57, 2014, pp. 989 - 998.

[7] V. Sakhare, V.N. Kapatkar, "Experimental Analysis of Parabolic Solar Dish with Copper Helical coil Receiver", Int.l Journal of Innovative Research in Adv. Eng. (IJIRAE), Vol. 1, Issue 8, 2014, pp. 199-204.

[8] R. Masood, S.I. Gilani, H.H. Al-Kayiem, "Thermal Output Analysis of a Designed
Parabolic Trough Solar Field for Moderate Temperature Industrial Load", Int. Journal of Eng. and Tech. (IJET), Vol. 8, No. 2, 2016, pp. 1018-1024.

[9] H.B. Kulkarni, "Design and Development of Prototype Cylindrical Parabolic Solar Collector for Water Heating Application", Int. Journal of Ren. Energy Development (IJRED), Vol. 5, No. 1, 2016, pp. 49-55.

[10] S.R. Pavlovic, E.A. Bellos, V.P. Stefanovic, C. Tzivanidis, Z.M. Stamenkovic, "Design, Simulation and Optimization of a Solar Dish Collector with Spiral-Coil Thermal Absorber", Thermal Science, Vol. 20, No. 4, 2016, pp. 1387-1397.

[11] D. Kumar, S. Kumar, "Thermal Performance of the Solar Parabolic Trough Collector at Different Flow Rates: An Experimental Study", International Journal of Ambient Energy, Published online: 6 Jan 2017.

https://doi.org/10.1080/01430750.2016.1269673

[12] Syed Mohd. Yasir Arsalan, Er. Earnest Vinay Prakash, Er. Rahul Charles Francis, "Performance Evaluation of Solar Parabolic Trough Collector with Stainless Steel Sheet as a Reflector", Int. Journal of Eng. Research \& Science (IJOER), Vol. 2, Issue. 6, 2016, pp. 22-28.

[13] B.C. Ankanna, B.S. Reddy, "Performance Analysis of Fabricated Helical Coil Heat Exchanger", Int. Journal of Eng. Research, Vol. 3, 2014, pp: 33-39.

[14] K. Rajalingam, "Light Dependent Resistor with Arduino", C\# Corner, 12 Feb 2016.

[15] W.Durfee, "Arduino Microcontroller Guide", University of Minnesota-version, Oct. 2011.

[16] J.A. Duffie, W.A. Beckman, "Solar Engineering of Thermal Processes", John Wiley and Sons Inc. $4^{\text {th }}$ Edition 2013.

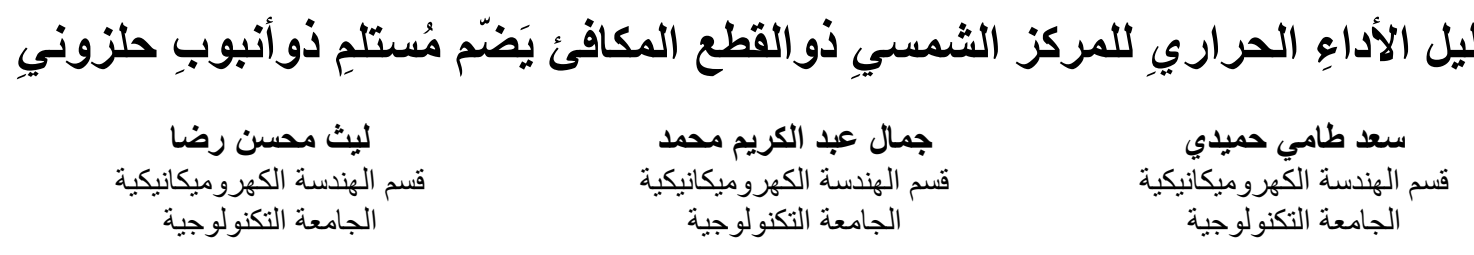

الخلاصة:

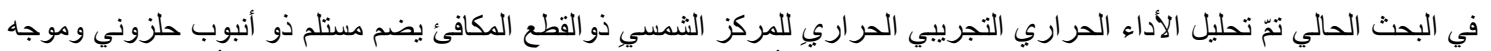

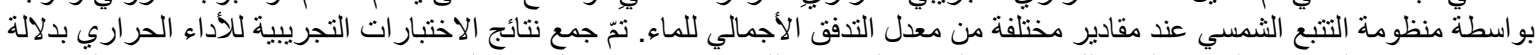

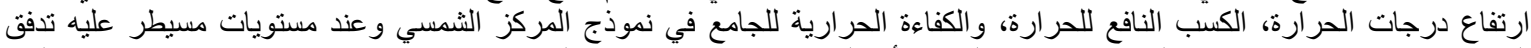

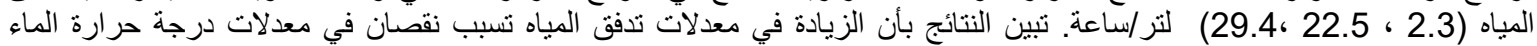

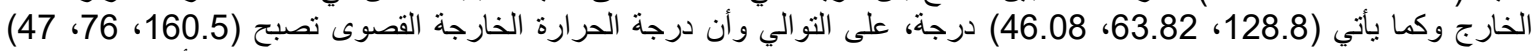

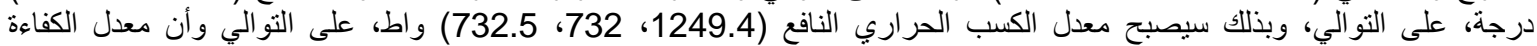

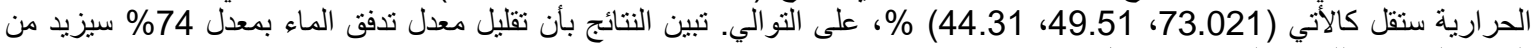

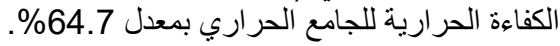

